\title{
Proenkephalin: A New Biomarker for Glomerular Filtration Rate and Acute Kidney Injury
}

\author{
Mina Khorashadi $^{a}$ Remi Beunders $^{\mathrm{b}}$ Peter Pickkers ${ }^{\mathrm{b}}$ Matthieu Legrand ${ }^{\mathrm{a}}$ \\ aDepartment of Anesthesiology and Peri-Operative Medicine, University of California, San Francisco, CA, USA; \\ ${ }^{b}$ Department of Intensive Care Medicine, Radboud University Medical Hospital, Nijmegen, The Netherlands
}

\section{Keywords}

Acute kidney injury · Biomarkers · Creatinine · Glomerular filtration rate Proenkephalin

\begin{abstract}
Assessment of kidney function is primarily based on urine output and Creatinine ( $\mathrm{Cr}$ )-based methods to estimate glomerular filtration rate (GFR). The latter is confounded as $\mathrm{Cr}$ is not exclusively filtered by the kidney and rises relatively late after the onset of acute kidney injury (AKI). This leads to delays in recognition of reduced kidney function and diagnosis of AKI, particularly in critically ill patients where kidney function can change rapidly. The gold standard methods of GFR determination, such as inulin or iohexol clearance, are labor intensive and unfeasible in acute clinical settings. Proenkephalin A 119-159 (PENK) has been intensively studied as a novel biomarker of kidney function. PENK belongs to the enkephalin peptide family and is freely filtrated in the glomerulus. Plasma PENK concentration appears to correlate strongly with GFR. Moreover, increased plasma PENK concentrations are found to be associated with long-term kidney outcomes and mortality. In this review, we summarize the role of PENK in assessment of kidney function and its capacity to predict various clinical outcomes.
\end{abstract}

(c) 2020 The Author(s)

Published by S. Karger AG, Basel

karger@karger.com www.karger.com/nef

Karger $\stackrel{\text { ' }}{5}$

GOPEN ACCESS
(C) 2020 The Author(s)

Published by S. Karger AG, Basel

This article is licensed under the Creative Commons AttributionNonCommercial-NoDerivatives 4.0 International License (CC BYNC-ND) (http://www.karger.com/Services/OpenAccessLicense). Usage and distribution for commercial purposes as well as any distribution of modified material requires written permission.

\section{Introduction}

Acute kidney injury (AKI) is common and strongly associated with adverse outcomes [1]. Next to a reduction in urine output, AKI is currently defined on the basis of increasing serum $\mathrm{Cr}$ concentrations as a surrogate measure for glomerular filtration rate (GFR). However, serum $\mathrm{Cr}$ is notoriously unreliable as it is affected by confounding factors such as volume status, muscle mass and metabolism, nutrition, and medication [2]. Furthermore, because of a long half-life of $\mathrm{Cr}$ and active secretion in renal tubules, concentrations increase late after reduction of GFR, leading to delays in detection of an acute decrease in renal function. As a result, Cr-based methods of GFR estimations are not validated in non-steady-state settings where kidney function can change rapidly [3]. Due to these limitations, multiple novel biomarkers are being in-

Peter Pickkers and Matthieu Legrand contributed equally to the manuscript.

Contribution from the AKI and CRRT 2020 Symposium at the 25th International Conference on Advances in Critical Care Nephrology, Manchester Grand Hyatt, San Diego, CA, USA, February 24-27, 2020. This symposium was supported in part by the NIDDK funded University of Alabama at Birmingham-University of California San Diego O'Brien Center for Acute Kidney Injury Research (P30DK079337).

Peter Pickkers

Department of Intensive Care Medicine, Radboud University Medical Hospital Geert Grooteplein Zuid 10

NL-6525GA Nijmegen (The Netherlands)

peter.pickkers@ radboudumc.nl 
vestigated to fulfill the unmet medical need for an accurate biomarker for kidney function in non-steady-state situations.

Proenkephalin A 119-159 (PENK) has recently been described as an accurate biomarker of kidney function, as sensitive in detection of AKI, and as being associated with impaired outcomes in various clinical settings, including critical illness, sepsis, heart failure, CKD, and in kidney transplant recipients and donors [4-13]. In this review, we summarize the role of PENK in assessment of kidney function and its association with clinical outcomes.

\section{Enkephalins and the Kidney}

Preproenkephalin A is the precursor molecule of the enkephalin family. Cleavage of this pro-peptide yields PENK and several biologically active enkephalins, including met-enkephalin and leu-enkephalin. Enkephalins are endogenous opioids that are widely expressed and act primarily on delta opioid receptors [14]. Intriguingly, the highest density of delta opioid receptors, second to the central nervous system, is found in the kidney [15]. While the exact function of enkephalins on the kidney is not fully known, human and animal studies suggest a possible regulatory role on kidney function such as inducing diuresis and natriuresis through receptor agonism [16] or inhibiting antidiuretic hormone [17]. A compensatory upregulation, decrease in clearance, or both may account for the increase in met-enkephalin levels in patients with renal disease [18]. Biologically active enkephalins are difficult to measure due to their short half-lives and instability after collection $[19,20]$. PENK has a long in vivo halflife, is stable after collection, and its levels are not influenced by age or sex [5], making it a suitable surrogate measure of its biologically active counterparts [21]. Furthermore, PENK is not protein bound in plasma and is exclusively filtrated in the glomerulus, making it an promising biomarker for kidney function in critically ill patients $[4,5]$.

\section{PENK as a Biomarker of GFR}

In various patient populations, plasma PENK concentrations strongly correlate with GFR (Table 1). Notably, PENK compared to Cr-based methods, appears to have a stronger correlation with the measured GFR (mGFR) in non-steady-state settings. In a study in septic shock patients, plasma PENK concentrations showed a very strong correlation with measured GFR using the gold standard iohexol plasma clearance $\left(\mathrm{mGFR}_{\text {iohexitol }}\right)\left(R^{2}=0.90, p<\right.$ 0.0001 ) [7]. In the same study, there was considerable variability and bias in the Cr-based GFR estimations; the eGFR $_{\text {MDRD }}$ overestimated the true GFR with $31 \pm 35 \%$ (95\% limits of agreement: -37 to $100 \%$ ) and the $\mathrm{GFR}_{\mathrm{ECC}}$ with $37 \pm 49 \%$ (95\% limits of agreement: -59 to $133 \%$ ). The true GFR appeared to be more accurately reflected by plasma PENK concentration compared to Cr-based methods. In a large study $(n=1,191)$ in potential kidney donors, post-kidney donors, patients with CKD, kidney transplant recipients, and other non-kidney solid organ transplant recipients, PENK correlated with measured GFR using iothalamate clearance $(\beta=-0.77, p<0.0001)$ [5]. Receiver operating curve analysis in the same cohort showed an area under the receiver operating curve (AUROC) of $0.86(p<0.001)$ for identification of patients with GFR $<60 \mathrm{~mL} / \mathrm{min} / 1.73 \mathrm{~m}^{2}$.

The strong correlations between plasma PENK and mGFR indicate that PENK may be a suitable and accurate marker to estimate true GFR compared to current available methods. Furthermore, elevations in plasma PENK concentration appear to precede the rise in serum $\mathrm{Cr}$ concentrations $[8,22]$, which may make this novel biomarker particularly useful in critically ill patients whose kidney function may be changing rapidly. In combination with novel sensitive tubular injury markers, differentiating between rapid changes in GFR and actual renal damage can be combined. However, the signaling function of enkephalins or (patho)physiological situations that lead to an increased production of enkephalins are possible confounding factors.

\section{PENK as a Biomarker of AKI}

Association of PENK with AKI has been demonstrated in multiple cohorts of critically ill patients $[4,6,9,10$, 23-25]. In a study of 956 patients with sepsis, PENK independently predicted the occurrence of AKI within $48 \mathrm{~h}$ and 7 days of admission (adjusted OR = 3.3; CI [2.1-5.1] and adjusted $\mathrm{OR}=2.1$; CI [1.7-2.8], respectively) [6]. The median PENK levels increased with AKI severity according to the Kidney Disease: Improving Global Outcomes stage and with the renal Sequential Organ Failure Assessment (rSOFA) score. In a subgroup analysis of 299 patients with eGFR $>70 \mathrm{~mL} / \mathrm{min} / 1.73 \mathrm{~m}^{2}$ on admission, PENK levels were still associated with AKI (adjusted $\mathrm{OR}=1.9$; CI [1.0-3.4], $p=0.04)$. In another cohort of septic patients $(n=644)$, admission plasma PENK levels 
Table 1. PENK evaluated as functional biomarker

\begin{tabular}{|c|c|c|c|c|c|c|c|}
\hline $\begin{array}{l}\text { Marino } \\
\text { et al. [4] }\end{array}$ & $\begin{array}{l}\text { Sepsis (101) } \\
\text { Non-steady state }\end{array}$ & $\begin{array}{l}\text { Diagnostic accuracy to } \\
\text { detect AKI (RIFLE) } \\
\text { compared with NGAL }\end{array}$ & $\begin{array}{l}\text { PENK: } \chi 2=34.9 \\
p<0.001, \mathrm{AUC}=0.82\end{array}$ & \multirow{2}{*}{$\begin{array}{l}\text { Correlation with } \mathrm{Cr} \\
\text { clearance }\end{array}$} & \multicolumn{2}{|c|}{$r^{2}=0.52, p<0.0001$} & \\
\hline $\begin{array}{l}\text { Kim et al. } \\
{[23]}\end{array}$ & $\begin{array}{l}\text { Sepsis (167) } \\
\text { Non-steady state }\end{array}$ & $\begin{array}{l}\text { PENK versus NGAL in } \\
\text { detecting AKI (diagnosed } \\
\text { with KDIGO), compared } \\
\text { with eGFRs (MDRD and } \\
\text { CKD-EPI }_{\text {Cr/CystC/Cr-CystC) }}\end{array}$ & $\begin{array}{l}\text { AUC: PENK } 0.725, \text { NGAL } \\
0.675 \text {, not statistically } \\
\text { different. Nested logistic } \\
\text { regression: PENK superior } \\
\text { to NGAL }(p=0.022) \text {, } \\
\text { PENK was not superior } \\
\text { over eGFR }_{\text {CysC }}(p=0.473)\end{array}$ & & & & \\
\hline \multirow{2}{*}{$\begin{array}{l}\text { Matsue } \\
\text { et al. [8] }\end{array}$} & \multirow{2}{*}{$\begin{array}{l}\text { Chronic heart } \\
\text { failure } \\
\text { Steady state }\end{array}$} & \multirow{2}{*}{$\begin{array}{l}\text { Association with NGAL } \\
\text { and KIM-1 }\end{array}$} & KIM-1: $p=0.391$ & \multirow{2}{*}{$\begin{array}{l}\text { Association with RBF } \\
\text { and GFR using } \\
\text { 131I-hippuran and } \\
\text { 123I-iothalamate }\end{array}$} & GFR: -0.71 & -9.59 & $<0.001$ \\
\hline & & & & & RBF: -0.66 & -7.30 & $<0.001$ \\
\hline \multirow[t]{2}{*}{$\begin{array}{l}\text { Gayat } \\
\text { et al. [24] }\end{array}$} & \multirow{2}{*}{$\begin{array}{l}\text { Critically ill } \\
\text { patients }(200) \\
\text { Non-steady state }\end{array}$} & Nephrocheck and PENK & $\begin{array}{l}\text { AUROC: Nephrocheck: } \\
0.697(0.62-0.77)\end{array}$ & & & & \\
\hline & & $\begin{array}{l}\text { ROC curve for biomark- } \\
\text { ers for AKI (KDIGO) }\end{array}$ & PENK: 0.832 (0.77-0.89) & & & & \\
\hline $\begin{array}{l}\text { Caironi } \\
\text { et al. [6] }\end{array}$ & $\begin{array}{l}\text { Sepsis (956) } \\
\text { Non-steady state }\end{array}$ & & & Correlation with $\mathrm{Cr}$ & Spearman $r=$ & $.74, p<$ & 001 \\
\hline \multirow{4}{*}{$\begin{array}{l}\text { Kieneker } \\
\text { et al. [30] }\end{array}$} & $\begin{array}{l}\text { Renal transplant } \\
\text { recipients }(664) \\
\text { Steady state }\end{array}$ & & & Recipients: & Recipients: & & \\
\hline & \multirow{3}{*}{$\begin{array}{l}\text { Kidney donors (95) } \\
\text { Steady state }\end{array}$} & & & $\begin{array}{l}\text { 1. Correlation } \\
\text { with } \mathrm{mGFR}_{\mathrm{I} 125 \text {-iothalamate }}\end{array}$ & 1. $\mathrm{mGFR} r_{\mathrm{s}}=$ & $-0.74, p$ & 001 \\
\hline & & & & $\begin{array}{l}\text { 2. Correlation } \\
\text { with eGFR } \\
\text { CKD-EPI }\end{array}$ & 2. $\mathrm{eGFR}_{\mathrm{CKD}-1}$ & $r_{\mathrm{s}}=-0$ & $D<0.001$ \\
\hline & & & & 3. Correlation with $\mathrm{Cr}$ & 3. $\mathrm{Cr} r_{\mathrm{s}}=0.6$ & $<0.001$ & \\
\hline $\begin{array}{l}\mathrm{Ng} \\
\text { et al. [26] }\end{array}$ & $\begin{array}{l}\text { Acute HF }(1,098) \\
\text { Non-steady state }\end{array}$ & & & Correlation with eGFR & $r_{\mathrm{s}}=-0.752 ; 1$ & 0.0005 & \\
\hline $\begin{array}{l}\text { Kanagala } \\
\text { et al. [27] }\end{array}$ & $\begin{array}{l}\text { HFpEF (522) } \\
\text { Steady state }\end{array}$ & & & Correlation with eGFR & $r_{\mathrm{s}}=-0.741 ; 1$ & 0.0005 & \\
\hline \multirow{2}{*}{$\begin{array}{l}\text { Emmens } \\
\text { et al. [12] }\end{array}$} & \multirow{2}{*}{$\begin{array}{l}\text { New onset or } \\
\text { worsening HFpEF } \\
(n=2,189) \\
\text { Non-steady state }\end{array}$} & & & Correlation with eGFR & eGFR $r_{\mathrm{s}}=-0$ & $8 ; p<0$ & \\
\hline & & & & Correlation with $\mathrm{Cr}$ & Cr: $r_{\mathrm{s}}=0.49$ & $<0.001$ & \\
\hline $\begin{array}{l}\text { Beunders } \\
\text { et al. [7] }\end{array}$ & $\begin{array}{l}\text { Sepsis (23) } \\
\text { Non-steady state }\end{array}$ & & & $\begin{array}{l}\text { Correlation with } \\
\text { mGFR }_{\text {iohexital }}\end{array}$ & $\mathrm{GFR}_{\text {iohexol }} r^{2}$ & $0.90, p$ & 001 \\
\hline
\end{tabular}

AKI, acute kidney injury; NGAL, neutrophil gelatinase-associated lipocalin; PENK, proenkephalin; AUC, area under the curve; (e)GFR, (estimated) glomerular filtration rate; KIM, kidney injury molecule; RBF, renal blood flow; Stand, standardized; AUROC, area under the receiver operating curve; HF, heart failure; HFpEF, heart failure with preserved ejection fraction; KDIGO, Kidney Disease: Improving Global Outcomes; Cr, creatinine. 
Table 2. Prediction of outcome [4, 6, 8-13, 23, 26, 29, 31-34]

\begin{tabular}{|c|c|c|c|c|}
\hline Study & Population $(n)$ & Outcome parameter & Outcome & Comments \\
\hline \multirow{3}{*}{$\begin{array}{l}\text { Marino } \\
\text { et al. [4] }\end{array}$} & \multirow[t]{3}{*}{ Sepsis (101) } & \multirow[t]{3}{*}{ 7-day mortality } & PENK: $X^{2}=13.4, p<0.001, \mathrm{AUC}=0.69$ & \multirow{3}{*}{$\begin{array}{l}\text { PENK outperforms Cr clearance in predicting } \\
\text { 7-day mortality }\end{array}$} \\
\hline & & & Cr clearance: $X^{2}=4$ & \\
\hline & & & $p=0.045, \mathrm{AUC}=0.61$ & \\
\hline \multirow[t]{3}{*}{$\begin{array}{l}\text { Kim } \\
\text { et al. [23] }\end{array}$} & \multirow[t]{3}{*}{ Sepsis (167) } & \multirow[t]{2}{*}{ 1. 30-day mortality } & $\begin{array}{l}\text { 1. Optimal cutoff by ROC: } \mathrm{HR}=3.9 \text {; CI } \\
(1.7-8.6)\end{array}$ & \multirow{2}{*}{$\begin{array}{l}\text { 1. PENK performed similar compared with } \\
\text { eGFR calculations based son Cr and cystatin C. } \\
\text { PENK performed better than NGAL }\end{array}$} \\
\hline & & & Designated cutoff: $\mathrm{HR}=7.9 ; \mathrm{CI}(3.9-16.2)$ & \\
\hline & & 2. Need for RRT & 2. ROC: PENK, 0.87; NGAL, 0.74 & $\begin{array}{l}\text { 2. Based on ROC curve analyses, PENK } \\
\text { performed slightly better compared with NGAL }\end{array}$ \\
\hline \multirow[t]{2}{*}{$\begin{array}{l}\text { Schulz } \\
\text { et al. [13] }\end{array}$} & \multirow[t]{2}{*}{$\begin{array}{l}\text { Population-based } \\
\text { cohort }(2,568)\end{array}$} & 1. WRF & 1. Greater than annual decline of GFR & $\begin{array}{l}\text { 1. PENK significantly predicted faster GFR } \\
\text { decline and WRF }\end{array}$ \\
\hline & & 2. Incidence of CKD & $\begin{array}{l}\text { 2. During 16.6-year follow-up: OR = 1.34; } \\
95 \% \text { CI }(1.18-1.94)\end{array}$ & 2. Independently predicted incidence of CKD \\
\hline $\begin{array}{l}\text { Shah } \\
\text { et al. [31] }\end{array}$ & $\begin{array}{l}\text { Cardiac surgery } \\
(92)\end{array}$ & AKI postoperative & $\mathrm{OR}=23.8(p=0.011 ; 95 \% \mathrm{CI}[2-270])$ & $\begin{array}{l}\text { PENK significantly predicted AKI, similar to } \mathrm{Cr} \\
\text { baseline }\end{array}$ \\
\hline \multirow{3}{*}{$\begin{array}{l}\mathrm{Ng} \\
\text { et al. [26] }\end{array}$} & \multirow{3}{*}{$\begin{array}{l}\text { Acute heart } \\
\text { failure }(1,908)\end{array}$} & 1. 1-year mortality & 1. OR: independent predictor; $p<0.0005$ & \multirow{2}{*}{$\begin{array}{l}\text { 1,2. PENK predicted 1-year mortality and/or } \\
\text { HF }\end{array}$} \\
\hline & & 2. 1-year death and/or HF & 2. $\mathrm{HR}=1.27 ; 95 \% \mathrm{CI}(1.10-1.45)$ & \\
\hline & & 3. WRF & $\begin{array}{l}\text { 3. OR }=1.58 ; 95 \% \mathrm{CI}(1.24-2.00) ; p< \\
0.0005\end{array}$ & 3. PENK independently predicted WRF \\
\hline \multirow{2}{*}{$\begin{array}{l}\text { Matsue } \\
\text { et al. [8] }\end{array}$} & \multirow{2}{*}{$\begin{array}{l}\text { Acute heart } \\
\text { failure }(1,589)\end{array}$} & 1. WRF & 1. Predictor for WRF & 1. WRF: No addition to existing renal marker \\
\hline & & 2. 180-day mortality & $\begin{array}{l}\text { 2. Not independent predictor of prognosis } \\
\text { in AHF }\end{array}$ & 2. No predictor of prognosis in AHF \\
\hline $\begin{array}{l}\text { Arbit } \\
\text { et al. [32] }\end{array}$ & $\begin{array}{l}\text { Chronic heart } \\
\text { failure (200) }\end{array}$ & MACE & Higher incidence of MACE: $p<0.003$ & High PENK predicted MACE \\
\hline \multirow{3}{*}{$\begin{array}{l}\mathrm{Ng} \\
\text { et al. [33] }\end{array}$} & \multirow{3}{*}{$\begin{array}{l}\text { Acute myocardial } \\
\text { infarction }(1,141)\end{array}$} & 1. MACE & \multirow[t]{3}{*}{$1,2,3: p<0.001$} & \multirow{3}{*}{$\begin{array}{l}\text { 1, 2, 3: High PENK associated with higher } \\
\text { incidence of MACE, hospitalization, and } \\
\text { mortality }\end{array}$} \\
\hline & & 2. Hospitalization & & \\
\hline & & 3. 2-year mortality & & \\
\hline \multirow{4}{*}{$\begin{array}{l}\text { Caironi } \\
\text { et al. [6] }\end{array}$} & \multirow[t]{4}{*}{ Sepsis (956) } & 1. Incident AKI (KDIGO) & 1. $\mathrm{OR}=3.3 ; 95 \% \mathrm{CI}(2.1-5.1) ; p<0.0001$ & 1. PENK independently predicted AKI \\
\hline & & 2. Future RRT & $\begin{array}{l}\text { 2. } X^{2}=97.2 ; p<0.0001 ; \text { AUC, } 0.755 ; \text { OR: } \\
\text { standardized for an increase by one IQR, } \\
4.0(3.0-5.4)\end{array}$ & 2. PENK independently predicted future RRT \\
\hline & & $\begin{array}{l}\text { 3. Improvement in renal } \\
\text { function }\end{array}$ & 3. OR of $0.31(0.18-0.54), p<0.0001$ & $\begin{array}{l}\text { 3. Cr alone was significantly weaker in } \\
\text { predicting renal improvement }\end{array}$ \\
\hline & & 4. 90-day mortality & $\begin{array}{l}\text { 4. HR of } 1.5(1.2-1.8) \text { for one IQR increase } \\
\text { in PENK, } p<0.0001\end{array}$ & $\begin{array}{l}\text { 4. PENK was independent predictor of } 90 \text {-day } \\
\text { mortality }\end{array}$ \\
\hline \multirow[t]{3}{*}{$\begin{array}{l}\text { Hollinger } \\
\text { et al. [9] }\end{array}$} & \multirow[t]{3}{*}{ Sepsis (583) } & $\begin{array}{l}\text { 1. MAKE at } 7 \text { days (death, } \\
\text { RRT, persistent AKI) }\end{array}$ & \multirow[t]{3}{*}{$1,2,3: p<0.0001$} & \multirow{3}{*}{$\begin{array}{l}\text { PENK predicted MAKE, AKI, WRF, and renal } \\
\text { recovery. These results were validated in } \\
\text { FROG-ICU cohort }(n=526)\end{array}$} \\
\hline & & 2. Transient AKI (KDIGO) & & \\
\hline & & 3. WRF & & \\
\hline \multirow{3}{*}{$\begin{array}{l}\text { Rosenqvist } \\
\text { et al. [10] }\end{array}$} & \multirow{3}{*}{$\begin{array}{l}\text { Sepsis on } \\
\text { emergency } \\
\text { department (588) }\end{array}$} & 1. Incident of AKI & 1. $p<0.001$ & 1. No longer significant after adjusting for eGFR \\
\hline & & $\begin{array}{l}\text { 2. Progression of rSOFA } \\
\text { score from } 0 \text { to } \geq 1\end{array}$ & $\begin{array}{l}\text { 2. } \mathrm{OR}=3.2 ; \mathrm{CI}(1.1-9.1) ; p=0.033 \\
\text { (adjusted for eGFR) }\end{array}$ & $\begin{array}{l}\text { 2. PENK independently predicted progression } \\
\text { of rSOFA score }\end{array}$ \\
\hline & & 3. 28-day mortality & $\begin{array}{l}\text { 3. } \mathrm{OR}=1.6 ; \mathrm{CI}(1.1-2.3) ; p=0.02 \\
\text { (adjusted for eGFR) }\end{array}$ & $\begin{array}{l}\text { 3. PENK independently predicted mortality. } \\
\text { eGFR was not predictive of mortality }\end{array}$ \\
\hline
\end{tabular}


Table 2 (continued)

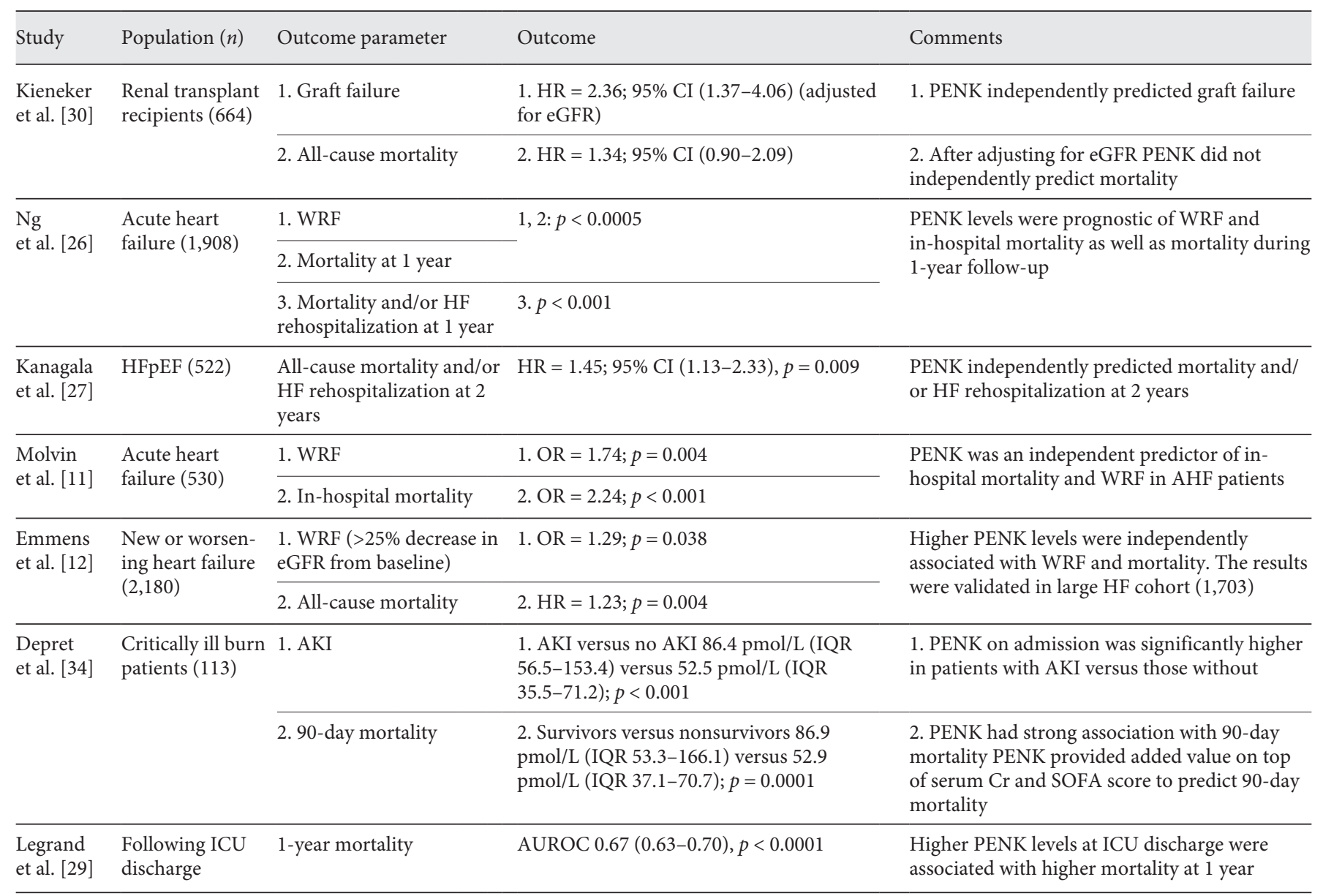

PENK, proenkephalin; AUC, area under the curve; RRT, renal replacement therapy; NGAL, neutrophil gelatinase-associated lipocalin; WRF, worsening of renal function; (e)GFR, (estimated) glomerular filtration rate; OR, odds ratio; MACE, major adverse cardiac event; IQR, interquartile range; HR, hazard ratio; RRT, renal replacement therapy; MAKE, major adverse kidney event; HFpEF, Heart failure with preserved ejection fraction; AKI, acute kidney injury; ICU, intensive care unit; AUROC, area under the receiver operating curve; rSOFA, renal Sequential Organ Failure Assessment; KDIGO, Kidney Disease: Improving Global Outcomes; Cr, creatinine.

predicted AKI within $48 \mathrm{~h}$ and 7 days [10]. Additionally, PENK levels significantly predicted progression of rSOFA scores from 0 to $\leq 1$ to higher rSOFA scores.

When compared to other biomarkers of kidney injury, PENK performed similar or better in detecting AKI. The diagnostic accuracy of PENK was similar to neutrophil gelatinase-associated lipocalin (NGAL) $\left(n=101, X^{2}=\right.$ 34.9, $p<0.001$, AUC $=0.82$ and $X^{2}=31.3, p<0.001$, $\mathrm{AUC}=0.80$, respectively) [4]. Notably, while PENK remained low in patients without or at risk of AKI, NGAL was elevated in patients without AKI, suggesting an impact of systemic inflammation on NGAL levels. Using nested logistic regression analysis, PENK outperformed NGAL for detection of AKI $(p=0.02)$. In a head-to-head comparison of PENK and the cycle cell arrest marker TIMP-2*IGFBP-7, a biomarker of kidney stress, PENK was superior in detecting renal failure in a cohort of 200 critically ill patients (area under the receiver operating curve 0.91 [0.71-0.84] versus 0.67 [0.59-0.74], respectively, $p<0.001)$ [24].

The association between PENK and development of AKI is possibly related to the strong correlation with the true GFR; an accurate reflection of the current GFR may provide a good signal for risk of future deterioration or improvement. It is also possible that the opioid receptors of the kidney and the signaling function of enkephalins account for the strong association with AKI. Finally, a combination of the 2 mentioned hypotheses may explain 
the association of PENK with AKI: a decreased filtration of PENK and simultaneously an increased production of PENK during a period of AKI. Studies on the endogenous clearance studies should investigate these hypotheses.

\section{Association of PENK with Clinical Outcome}

PENK has been studied as a prognostic marker of various clinical outcomes (Table 2). The kidney in sepsis and septic shock study $(n=583)$ evaluated the association of PENK with the composite outcome of the incidence of major adverse kidney event (MAKE) and worsening renal function (WRF) which was defined as an increase in serum Cr level by $\geq 1.5$-fold or $\geq 0.3 \mathrm{mg} / \mathrm{dL}(26.5 \mu \mathrm{mol} / \mathrm{L})$, or need for renal replacement therapy (RRT), or death within $48 \mathrm{~h}$ of admission [9]. Admission PENK plasma concentrations were independently associated with MAKE and WRF $(\mathrm{OR}=3.3[1.8-6.0], p<0.0001$ and $\mathrm{OR}=3.4$ [1.9-6.2], $p<0.0001$, respectively). Notably, when restricting the analysis to patients with low serum $\mathrm{Cr}$ on admission and patients without CKD, PENK was superior to serum $\mathrm{Cr}$ in predicting MAKE and WRF. In another large cohort of septic patients $(n=956)$, elevated plasma PENK concentrations predicted future need for RRT and 90-day mortality $\left(\mathrm{OR}_{\mathrm{RRT}}=4.0, \mathrm{CI}[3.0-5.4]\right.$ and $\mathrm{HR}_{\text {mortality }}=1.5$, CI $[1.2-1.8]$ ) independently of potential confounding factors [6]. Similar results were found in burn patients [25] and patients with acute heart failure ( $n=530[11]$ and $n=2,180$, respectively [12]). Other studies in heart failure patients have reported similar findings with regard to the association of PENK with these clinical outcomes $[8,26,27]$ which might partly be driven by enkephalin gene expression in cardiac muscle cells [28].

In a study of patients discharged alive from an intensive care unit $(n=1,207)$, higher PENK levels at discharge were independently associated with higher mortality at 1 year $(\mathrm{OR}=2.2$ [1.44-3.38]) [29]. Notably, in patients without severe renal dysfunction at discharge (based on serum $\mathrm{Cr}$ ), elevated PENK plasma concentrations were strongly associated with 1-year mortality. In a study of renal transplant recipients $(n=664)$ with a stable kidney function who were followed over a 3-year period, plasma PENK concentrations were associated with the risk of graft failure (defined as return to RRT or retransplantation) $\left(\mathrm{HR}_{\text {GraftFailure }}=4.80\right.$, CI [3.55-6.48]) [30]. PENK was also shown to predict future changes in kidney function in 2,568 individuals without CKD at baseline (eGFR
$>60 \mathrm{~mL} / \mathrm{min} / 1.73 \mathrm{~m}^{2}$ ) who were followed up for average of 16 years [13]. In this study, individuals with higher baseline PENK levels had greater yearly decline in mean eGFR and at higher risk for developing $\mathrm{CKD}(\mathrm{OR}=1.51$; CI [1.18-1.94]). Again, the accurate reflection of the GFR of PENK or a signaling function of enkephalins may enable the association with future renal disease or clinical outcome. Clearly, implementation of a new biomarker is always troublesome, and the reasons for this are similar for the different biomarkers: the availability, the price (compared to $\mathrm{Cr}$ ), and limited data available on the effect of PENK-based management on clinical outcome. Finally, despite early implementation of preventive and therapeutic strategies in patients at risk has been shown to improve outcome (i.e., Kidney Disease: Improving Global Outcomes bundles), the importance of early recognition of AKI might still be underappreciated by many clinicians and institutions.

\section{Conclusion}

In summary, in the search to find an accurate method to assess actual GFR in critically ill patients with a nonsteady-state kidney function, the available evidence suggests that PENK is a more accurate and precise surrogate marker to estimate GFR or to detect AKI compared to Cr-based methods. Furthermore, PENK is associated with precise prediction of future deterioration of kidney function and impaired outcome in various patient populations.

\section{Conflict of Interest Statement}

M.K. declared no conflicts of interests. R.B. received a travel reimbursement from Sphingotec GmbH. P.P. received travel and consultancy reimbursements and research support from Sphingotec $\mathrm{GmbH}$ and M.L. received research funds from the French Ministry of Health, research support from Sphingotec $\mathrm{GmbH}$, consulting reimbursements from Novartis, and lecture reimbursements from Baxter and Fresenius.

\section{Author Contributions}

All authors confirmed that they contributed to the intellectual content of this review. M.K. drafted the manuscript. R.B., P.P., and M.L. revised the manuscript. 


\section{References}

1 Hoste EAJ, Bagshaw SM, Bellomo R, Cely CM, Colman R, Cruz DN, et al. Epidemiology of acute kidney injury in critically ill patients: the multinational AKI-EPI study. Intensive Care Med. 2015 Aug;41(8):1411-23.

2 Shemesh O, Golbetz H, Kriss JP, Myers BD. Limitations of creatinine as a filtration marker in glomerulopathic patients. Kidney Int. 1985 Nov;28(5):830-8.

3 Levey AS, Bosch JP, Lewis JB, Greene T, Rogers N, Roth D. A more accurate method to estimate glomerular filtration rate from serum creatinine: a new prediction equation. Ann Intern Med. 1999 Mar 16;130(6):461-70.

4 Marino R, Struck J, Hartmann O, Maisel AS, Rehfeldt M, Magrini L, et al. Diagnostic and short-term prognostic utility of plasma proenkephalin (pro-ENK) for acute kidney injury in patients admitted with sepsis in the emergency department. J Nephrol. 2015 Dec; 28(6):717-24.

5 Donato LJ, Meeusen JW, Lieske JC, Bergmann D, Sparwaßer A, Jaffe AS. Analytical performance of an immunoassay to measure proenkephalin. Clin Biochem. 2018 Aug;58: 72-7.

6 Caironi P, Latini R, Struck J, Hartmann O, Bergmann A, Bellato V, et al. Circulating proenkephalin, acute kidney injury, and its improvement in patients with severe sepsis or shock. Clin Chem. 2018;64(9):1361-9.

7 Beunders R, van Groenendael R, Leijte G, Kox M, Pickkers P. Proenkephalin compared to conventional methods to assess kidney function in critically ill sepsis patients. Shock. 2020 Jan; 1 .

8 Matsue Y, Ter Maaten JM, Struck J, Metra M, O'Connor CM, Ponikowski P, et al. Clinical correlates and prognostic value of proenkephalin in acute and chronic heart failure. J Card Fail. 2017 Mar;23(3):231-9.

9 Hollinger A, Wittebole X, François B, Pickkers P, Antonelli M, Gayat E, et al. Proenkephalin A 119-159 (Penkid) is an early biomarker of septic acute kidney injury: the kidney in sepsis and septic shock (Kid-SSS) study. Kidney Int Rep. 2018 Nov;3(6):142433.

10 Rosenqvist $\mathrm{M}$, Bronton $\mathrm{K}$, Hartmann $\mathrm{O}$, Bergmann A, Struck J, Melander O. Proenkephalin a 119-159 (penKid): a novel biomarker for acute kidney injury in sepsis: an observational study. BMC Emerg Med. 2019 Nov 28;19(1):75.

11 Molvin J, Jujic A, Navarin S, Melander O, Zoccoli G, Hartmann O, et al. Bioactive adrenomedullin, proenkephalin a and clinical outcomes in an acute heart failure setting. Open Heart. 2019;6(2):e001048.
12 Emmens JE, ter Maaten JM, Damman K, van Veldhuisen DJ, de Boer RA, Struck J, et al. Proenkephalin, an opioid system surrogate, as a novel comprehensive renal marker in heart failure. Circ Heart Fail. 2019 May;12(5).

13 Schulz C-A, Christensson A, Ericson U, Almgren P, Hindy G, Nilsson PM, et al. High level of fasting plasma proenkephalin-a predicts deterioration of kidney function and incidence of CKD. J Am Soc Nephrol. 2017 Jan; 28(1):291-303.

14 Grossman A, Clement-Jones V. Opiate receptors: enkephalins and endorphins. Clin Endocrinol Metab. 1983 Mar;12(1):31-56.

15 Denning GM, Ackermann LW, Barna TJ, Armstrong JG, Stoll LL, Weintraub NL, et al. Proenkephalin expression and enkephalin release are widely observed in non-neuronal tissues. Peptides. 2008 Jan;29(1):83-92.

16 Sezen SF, Kenigs VA, Kapusta DR. Renal excretory responses produced by the delta opioid agonist, BW373U86, in conscious rats. J Pharmacol Exp Ther. 1998 Oct;287(1):23845.

17 Grossman A. Inhibition of vasopressin release in man by an opiate peptide. Lancet. 1980 Nov;316(8204):1108-10.

18 Smith R, Grossman A, Gaillard R, ClementJones V, Ratter S, Mallinson J, et al. Studies on circulating met-enkephalin and $\beta$-endorphin: normal subjects and patients with renal and adrenal disease. Clin Endocrinol. 1981 Sep; 15(3):291-300.

19 Andersen MB, Simonsen U, Wehland M, Pietsch J, Grimm D. LCZ696 (valsartan/sacubitril): a possible new treatment for hypertension and heart failure. Basic Clin Pharmacol Toxicol. 2016 Jan;118(1):14-22.

20 Sexton T, Hitchcook LJ, Rodgers DW, Bradley LH, Hersh LB. Active site mutations change the cleavage specificity of neprilysin. PloS One. 2012 Feb 23;7(2):e32343.

21 Ernst A, Köhrle J, Bergmann A. Proenkephalin A 119-159, a stable proenkephalin a precursor fragment identified in human circulation. Peptides. 2006 Jul;27(7):1835-40.

22 Beunders MM, Struck J, Pickkers P. ESICM lives 2019: Berlin, Germany. 28 September-2 October 2019. Intensive Care Med Exp. 2019 Sep;7(S3):55.

23 Kim H, Hur M, Lee S, Marino R, Magrini L, Cardelli P, et al. Proenkephalin, neutrophil gelatinase-associated lipocalin, and estimated glomerular filtration rates in patients with sepsis. Ann Lab Med. 2017;37(5):388-97.
24 Gayat E, Touchard C, Hollinger A, VieillardBaron A, Mebazaa A, Legrand M, et al. Backto-back comparison of penKID with NephroCheck $^{\circledast}$ to predict acute kidney injury at admission in intensive care unit: a brief report Crit Care. 2018 Dec;22(1):24.

25 Dépret F, Polina A, Amzallag J, Fayolle-Pivot L, Coutrot M, Chaussard M, et al. PenKid measurement at admission is associated with outcome in severely ill burn patients. Burns. 2020 Jan;S030541791930254-2.

26 Ng LL, Squire IB, Jones DJL, Cao TH, Chan DCS, Sandhu JK, et al. Proenkephalin, renal dysfunction, and prognosis in patients with acute heart failure: a great network study. J Am Coll Cardiol. 2017 Jan 3;69(1):56-69.

27 Kanagala P, Squire IB, Jones DJL, Cao TH, Chan DCS, McCann G, et al. Proenkephalin and prognosis in heart failure with preserved ejection fraction: a great network study. Clin Res Cardiol. 2019 Aug;108(8):940-9.

28 Barron B. Opioid peptides and the heart. Cardiovasc Res. 1999 Jul;43(1):13-6.

29 Legrand M, Hollinger A, Vieillard-Baron A, Dépret F, Cariou A, Deye N, et al. One-year prognosis of kidney injury at discharge from the ICU: a multicenter observational study. Crit Care Med. 2019 Dec;47(12):e953-61.

30 Kieneker LM, Hartmann O, Struck J, Bergmann A, Gansevoort RT, Joosten MM, et al. Plasma proenkephalin and poor long-term outcome in renal transplant recipients. Transplant Direct. 2017 Aug;3(8):e190.

31 Shah K, Taub P, Patel M, Rehfeldt M, Struck J, Clopton P, et al. Proenkephalin predicts acute kidney injury in cardiac surgery patients. Clin Nephrol. 2015;83(1):29-35. $10.5414 / \mathrm{cn} 108387.25512100$

32 Arbit B, Marston N, Shah K, Lee E, Aramin H, Clopton P, et al. Prognostic Usefulness of Proenkephalin in Stable Ambulatory Patients With Heart Failure. Am J Cardiol. 2016; 117(8): 1310-4. 10.1016/j.amjcard.2016.01. 042. 26916537

33 Ng L, Sandhu J, Narayan H, Quinn P, Squire I, Davies J, et al. Proenkephalin and prognosis after acute myocardial infarction. J Am Coll Cardiol. 2014;63(3):280-9. 10.1016/j.jacc. 2013.09.037. 24140658.

34 Dépret F, Polina A, Amzallag J, Fayolle-Pivot L, Coutrot M, Chaussard M, et al., PRONOBURN group. PenKid measurement at admission is associated with outcome in severely ill burn patients. Burns. 2020. 10.1016/j. burns.2020.01.002. 31987659 